\title{
PERANCANGAN KONVERTER ARUS SEARAH TIPE FLYBACK SEBAGAI CATU DAYA RANGKAIAN DRIVER DAN MICROCONTROLLER PADA KONVERTER TIPE ZETA
}

\author{
Gilang Cahyo Nugroho*), Trias Andromeda, and Yuli Christyono \\ Departemen Teknik Elektro, Universitas Diponegoro Semarang \\ Jl. Prof. Sudharto, SH, Kampus UNDIP Tembalang, Semarang 50275, Indonesia \\ ${ }^{*}$ E-mail: gilang.cahyon@gmail.com
}

\begin{abstract}
Abstrak
Hampir semua catu daya modern bekerja dalam mode switching atau dikenal sebagai SMPS (Switched Mode Power Supply), salah satu dari topologi yang dipakai adalah konverter arus searah tipe Flyback. Penambahan kontrol umpan balik tegangan dapat digunakan untuk menjaga kestabilan tegangan keluaran konverter arus searah. Pada penelitian ini akan direalisasikan sebuah konverter arus searah tipe Flyback dengan umpan balik tegangan yang menghasilkan tegangan keluaran sebesar $15 \mathrm{~V}$ dan $9 \mathrm{~V}$ untuk menyuplai rangkaian driver dan microcontroller pada konverter tipe Zeta dalam sistem Hybrid Charger Controller. Kontrol PWM pada penelitian ini menggunakan IC TL494. Pada penelitian ini, dilakukan pengujian konverter dengan umpan balik tegangan menggunakan variasi beban resistif. Hasil pengujian konverter dengan umpan balik tegangan pada sisi keluaran 9V diperoleh tegangan keluaran tetap terjaga sebesar 9V ketika diberi variasi beban resistif $330 \Omega$ sampai $47 \Omega$. Namun pada sisi keluaran $15 \mathrm{~V}$ terdapat penurunan tegangan dari $14,83 \mathrm{~V}$ dengan beban $330 \Omega$ ke $14,57 \mathrm{~V}$ dengan beban $47 \Omega$ karena pada sisi keluaran $15 \mathrm{~V}$ hanya menyesuaikan perubahan duty cycle dari sisi keluaran 9V. Dengan penambahan kontrol umpan balik tegangan pada konverter arus searah tipe Flyback menghasilkan nilai tegangan keluaran yang lebih stabil dengan adanya perubahan nilai beban.
\end{abstract}

Kata kunci: Konverter arus searah tipe Flyback, IC TL494, umpan balik tegangan

\begin{abstract}
Almost all modern power supplies work in switching mode or known as SMPS (Switched Mode Power Supply), one of the topologies used is a Flyback converter. The addition of voltage feedback control can be used to maintain stable voltage of converter output. In this research will be realized a Flyback converter with voltage feedback that produces output voltage of $15 \mathrm{~V}$ and $9 \mathrm{~V}$ to supply driver and microcontroller circuit on the Zeta converter in Hybrid Charger Controller system. The PWM control of this research uses IC TL494. In this research, tested the converter with voltage feedback using resistive load variation. The result of converter test with voltage feedback at output side $9 \mathrm{~V}$ obtained output voltage is maintained at $9 \mathrm{~V}$ when given resistive load variation of $330 \Omega$ to $47 \Omega$. But on the output side of $15 \mathrm{~V}$ there is a voltage drop from $14.83 \mathrm{~V}$ with a load of $330 \Omega$ to $14.57 \mathrm{~V}$ with a $47 \Omega$ load because on the output side $15 \mathrm{~V}$ only adjusts the duty cycle change from the output side of $9 \mathrm{~V}$. With the addition of voltage feedback control on the Flyback converter produces a more stable output voltage value with the change of load value.
\end{abstract}

Keywords: Flyback converter, IC TL494, voltage feedback

\section{Pendahuluan}

Sistem catu daya yang bekerja dalam mode pensaklaran (switching) mempunyai efisiensi lebih tinggi dibanding sistem catu daya linier. Oleh karena itu, hampir semua catu daya modern bekerja dalam mode switching atau dikenal sebagai SMPS (Switched Mode Power Supply). Konverter arus searah tipe Flyback merupakan konverter yang memiliki isolasi di antara masukan dan keluarannya. Ketika MOSFET dalam kondisi on, tegangan sumber akan mengalir melewati induktansi magnetik trafo $\left(\mathrm{L}_{\mathrm{m}}\right)$ dan menyebabkan arus induktansi magnetik ( $\left.i_{\text {Lm }}\right)$ naik secara linier dan dioda di bagian output bersifat reverse bias. Ketika MOSFET dalam kondisi off, energi yang tersimpan di dalam induktansi magnetik akan disalurkan melalui kumparan trafo dan dioda pada bagian output bersifat forward bias sehingga arus dapat disalurkan ke beban [1]. Penelitian mengenai konverter arus searah tipe Flyback dengan beragam tegangan keluaran pernah dilakukan oleh Yogi Sawitra [2]. Pada penelitian tersebut dibahas mengenai konverter arus searah tipe Flyback yang dirancang untuk menghasilkan tegangan keluaran 3,3V; $5 \mathrm{~V}$; dan $12 \mathrm{~V}$. Penelitian lain yang dilakukan oleh Argianka Satrio Putra [3] membahas mengenai perancangan 
konverter arus searah tipe Push-Pull dengan umpan balik tegangan menggunakan IC TL494. Pada penelitian oleh Eko Satrio Wardanu Prakoso [4] membahas mengenai perancangan konverter arus searah tipe Zeta dengan umpan balik tegangan menggunakan IC TL494. Sedangkan penelitian oleh Lukman Wira Cahyadi [5] membahas mengenai kinerja konverter arus searah tipe Buck Converter dengan umpan balik tegangan berbasis TL494.

Pada penelitian ini akan direalisasikan sebuah konverter arus searah tipe Flyback dengan umpan balik tegangan menggunakan IC TL494 yang menghasilkan tegangan keluaran sebesar $15 \mathrm{~V}$ dan $9 \mathrm{~V}$ untuk menyuplai rangkaian driver dan microcontroller pada konverter tipe Zeta dalam sistem Hybrid Charger Controller.

Adapun tujuan utama dari penelitian ini adalah sebagai berikut:

1. Mengimplementasikan konverter arus searah tipe Flyback sebagai catu daya rangkaian driver dan microcontroller pada konverter tipe Zeta dalam sistem Hybrid Charger Controller.

2. Menganalisis pengaruh kontrol umpan balik tegangan pada lebar pulsa PWM yang dihasilkan oleh IC TL494.

3. Menganalisis pengaruh umpan balik tegangan berbasis IC TL494 pada tegangan keluaran konverter arus searah tipe Flyback.

\section{Metode}

Pembagian blok pada penelitian ini terdiri dari rangkaian konverter Flyback, rangkaian MOSFET driver, dan rangkaian pembangkit sinyal PWM.

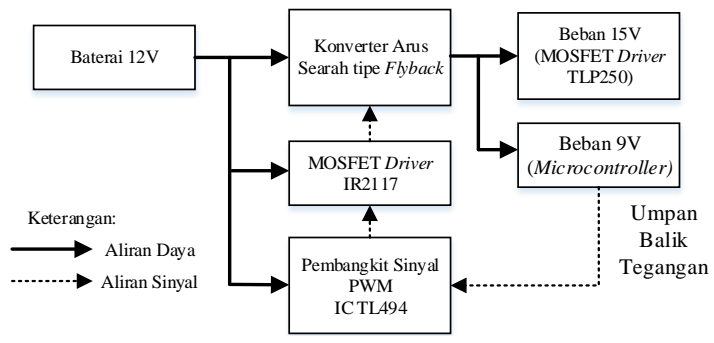

Gambar 1. Diagram Blok Alat Secara Keseluruhan

\subsection{Konverter Arus Searah tipe Flyback}

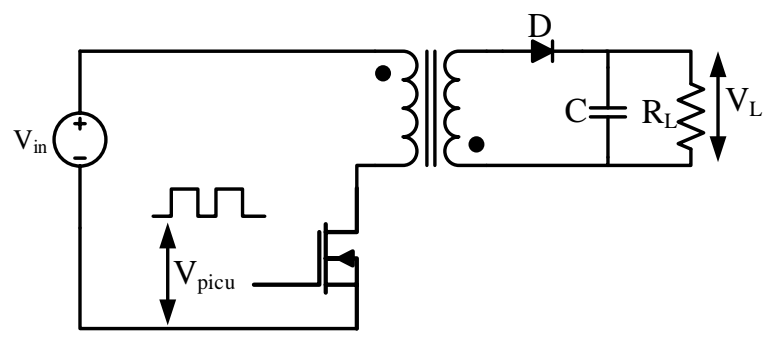

Gambar 2. Rangkaian Konverter Arus Searah Tipe Flyback
Rangkaian konverter arus searah tipe Flyback pada penelitian ini terdiri dari komponen-komponen berikut:

1. Sumber Tegangan DC $\left(V_{\text {in }}\right)$

Sumber tegangan yang digunakan sebagai suplai daya konverter berasal dari baterai $12 \mathrm{~V}$ berkapasitas 7,2Ah.

2. Saklar

Komponen pensaklaran yang digunakan pada konverter tersebut adalah MOSFET. MOSFET yang digunakan adalah IRF540N yang mampu menahan tegangan hingga 100V [6].

3. Transformator

Transformator pada penelitian ini digunakan untuk mengubah tingkat tegangan keluaran konverter arus searah tipe Flyback. Parameter tegangan masukan yang diharapkan bernilai $12 \mathrm{~V}$ dan tegangan keluaran yang diharapkan bernilai $15 \mathrm{~V}$ dan $9 \mathrm{~V}$. Sehingga diperoleh 4 lilitan pada sisi primer, 6 lilitan pada sisi sekunder $15 \mathrm{~V}$, dan 3 lilitan pada sisi sekunder 9V.

4. Dioda Penyearah

Dioda penyearah pada konverter arus searah tipe Flyback digunakan untuk menyearahkan tegangan keluaran pada sisi sekunder transformator. Dioda yang digunakan yaitu SR5100 pada masing-masing sisi tegangan keluaran konverter arus searah tipe Flyback. Dioda SR5100 merupakan dioda schottky yang memiliki kemampuan menghantarkan arus sampai 5A dan tegangan sebesar 100V [7].

5. Tapis Kapasitor

Tapis kapasitor berfungsi untuk mengurangi riak hasil dari penyearahan oleh dioda. Nilai kapasitor yang digunakan pada rancangan konverter arus searah tipe Flyback ini adalah $220 \mu \mathrm{F} / 50 \mathrm{~V}$ merek Rubycon [8] pada masing-masing sisi tegangan keluaran $15 \mathrm{~V}$ dan $9 \mathrm{~V}$.

\subsection{Rangkaian Kontrol PWM IC TL494 dengan Umpan Balik Tegangan}

Pada penelitian ini, sinyal PWM dihasilkan oleh IC TL494. IC TL494 dapat digunakan untuk kontrol umpan balik tegangan konverter arus searah tipe Flyback. Frekuensi PWM keluaran IC T1494 $\left(f_{\text {osc }}\right)$ diatur oleh dua komponen resistor timer $\left(R_{T}\right)$ dan capacitor timer $\left(C_{T}\right)$ [9].

$$
\begin{aligned}
& f_{o s c}=\frac{1}{R_{T} \cdot C_{T}} \\
& f_{\text {osc }(\max )}=\frac{1}{20000 \times 1 \times 10^{-9}}=50000 \mathrm{~Hz}\left(R_{V A R}=0 \Omega\right) \\
& f_{\text {osc }(\max )}=\frac{1}{70000 \times 1 \times 10^{-9}}=14285 \mathrm{~Hz}\left(R_{V A R}=50 \mathrm{k} \Omega\right)
\end{aligned}
$$

Pada perhitungan di atas, frekuensi switching rangkaian kontrol IC TL494 dapat diatur dengan range sebesar 14285 $\mathrm{Hz}-50000 \mathrm{~Hz}$. Pada perancangan rangkaian kontrol PWM 
ini, diterapkan frekuensi switching sebesar $25 \mathrm{kHz}$, frekuensi ini diperoleh dari pengaturan $R_{V A R}$.

Umpan balik tegangan digunakan untuk memonitor tegangan yang berfungsi menyesuaikan tegangan keluaran konverter dengan tegangan referensi pada pin 2 (inverting). Diketahui tegangan referensi error amplifier (Vref) sebesar $5 \mathrm{~V}$, maka perhitungan resistor $R_{1}$ dan $R_{2}$ sebagai berikut.

$V_{O U T}=V_{R E F}\left(1+\frac{R_{1}}{R_{2}}\right)$

$9=5\left(1+\frac{R_{1}}{R_{2}}\right)$

$R_{1}=0,8 R_{2}$

$R_{2}=1,25 R_{1}$

Pada perhitungan di atas, dibutuhkan nilai $R_{l}$ sebesar 0,8 kali $R_{2}$. Potensiometer $1 \mathrm{k} \Omega$ yang diatur sebesar $800 \Omega$ digunakan untuk merealisasikan $R_{1}$, maka nilai $R_{2}$ sebesar $1 \mathrm{k} \Omega$. Potensiometer $10 \mathrm{k} \Omega$ dapat digunakan untuk mengatur skala tegangan keluaran untuk memvariasikan tegangan masukan pin 1 IC TL494.

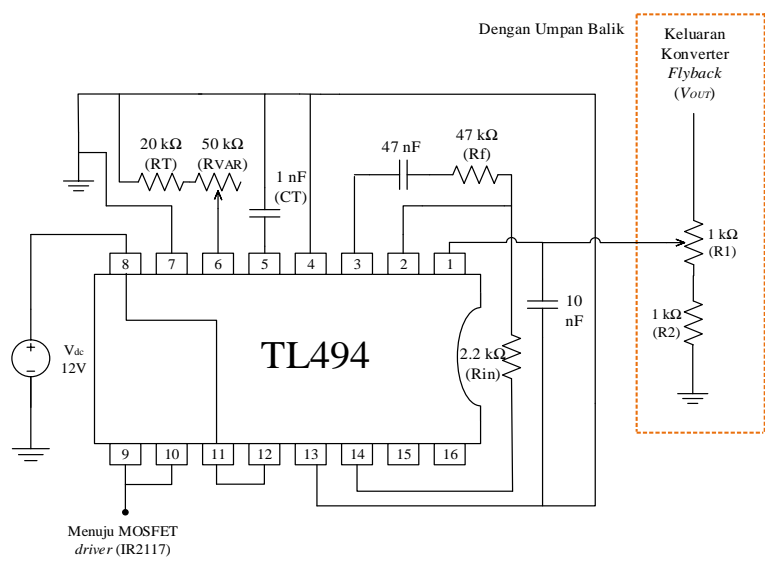

Gambar 3. Rangkaian Kontrol PWM IC TL494 dengan Umpan Balik Tegangan

\subsection{Rangkaian MOSFET Driver IR2117}

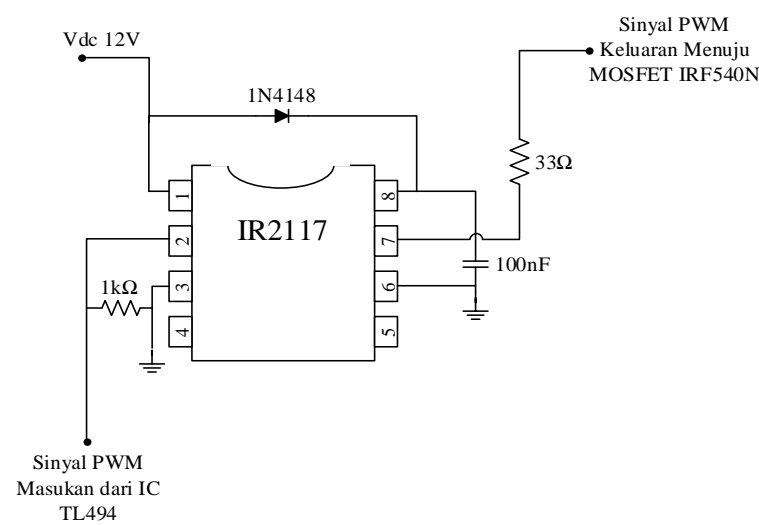

Gambar 4. Rangkaian MOSFET Driver IR2117
Gambar 4. di atas merupakan rangkaian MOSFET driver IR2117 yang digunakan sebagai penguat sinyal keluaran dari rangkaian kontrol PWM IC TL494. Mode sinyal keluaran dari IC TL494 adalah single-ended operation. Pada mode tersebut, IC TL494 menghasilkan satu keluaran gelombang PWM.

Pada Gambar 4., driver mendapat suplai tegangan DC yang berasal dari baterai $12 \mathrm{~V}$. Terdapat kapasitor $100 \mathrm{nF}$ yang menghubungkan pin 8 dan pin 6. Kapasitor ini adalah kapasitor decoupling, kapasitor ini dipasang agar meminimalisir noise tegangan suplai IC [10]. Terdapat dioda $1 \mathrm{~N} 4148$ yang terhubung pada pin 1 dan pin 8 untuk mencegah adanya arus negatif dari sisi logika keluaran driver yang terhubung dengan MOSFET menuju sisi suplai tegangan. Resistor $1 \mathrm{k} \Omega$ yang menghubungkan pin 2 dan ground berfungsi sebagai resistor pull down, sementara resistor $33 \Omega$ yang terhubung pin 7 menuju gate MOSFET berfungsi sebagai pembatas arus sinyal keluaran IR2117.

\section{Hasil dan Analisis}

\subsection{Pengujian Konverter Arus Searah Tipe Flyback dengan Umpan Balik Tegangan}

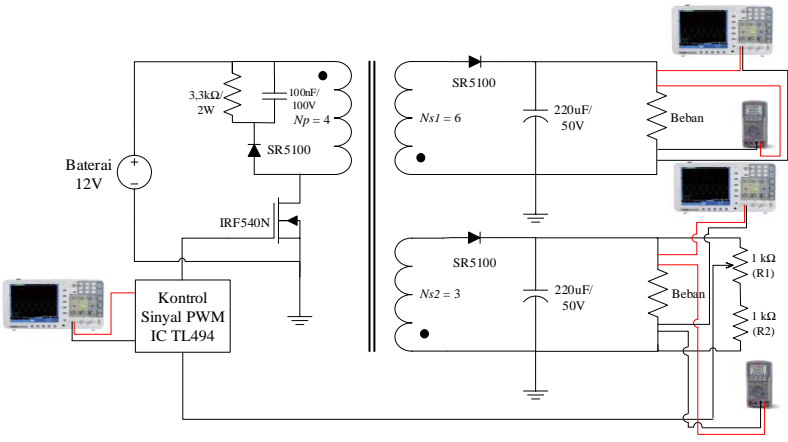

Gambar 5. Pengujian Konverter Arus Searah Tipe Flyback dengan Umpan Balik Tegangan

Pengujian dilakukan dengan mengambil data dari beban $330 \Omega$ hingga $47 \Omega$. Hal ini bertujuan untuk mengetahui pengaruh umpan balik tegangan terhadap perubahan beban.

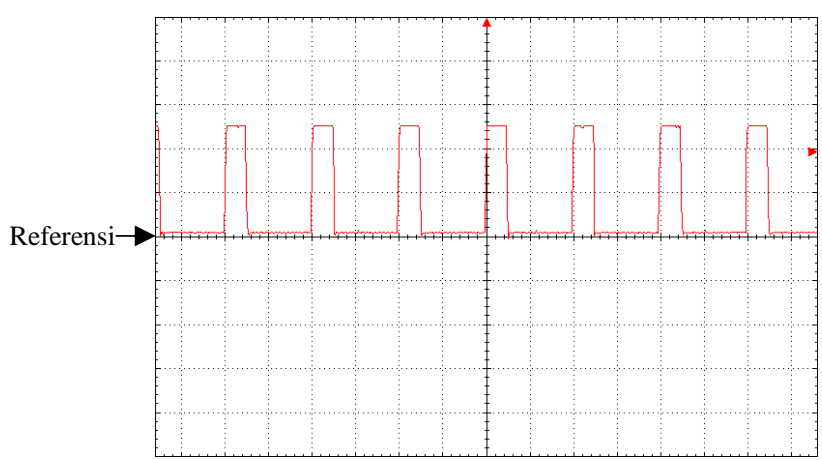

Gambar 6. Gelombang Sinyal PWM ketika Dibebani Resistor 330 $\Omega$. V/div $=5 \mathrm{~V}, \mathrm{~T} / \mathrm{div}=20 \mu \mathrm{s}$ 
Hasil pengamatan gelombang PWM keluaran IC TL494 saat konverter dibebani resistor $330 \Omega$ ditunjukkan Gambar 6. di atas.

Gambar 6. menunjukkan gelombang sinyal PWM ketika konverter arus searah tipe Flyback dengan umpan balik tegangan dibebani resistor $330 \Omega$. Osiloskop menunjukkan PWM yang dihasilkan memiliki duty cycle 24,2\%. Besar keluaran duty cycle PWM tersebut merupakan hasil respon IC TL494 terhadap tegangan keluaran konverter ketika dibebani resistor $330 \Omega$.

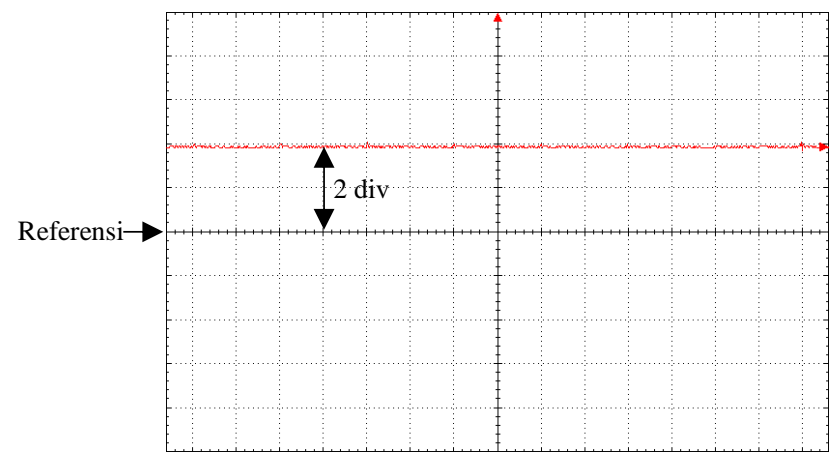

Gambar 7. Gelombang Tegangan Keluaran Sisi 9V dengan Beban Resistif 330 $\Omega$. V/div $=5 \mathrm{~V}, \mathrm{~T} / \mathrm{div}=20 \mu \mathrm{s}$

Gambar 7. merupakan gelombang tegangan keluaran sisi 9V dari konverter arus searah tipe Flyback dengan umpan balik tegangan dibebani resistor 330 . Pada Gambar 7., terlihat besarnya tegangan yaitu sebesar 2 div sehingga dapat dihitung besaran tegangan keluaran sebagai berikut.

$$
\begin{aligned}
V_{D C} & =2 \text { div } \times 5 \mathrm{~V} / \mathrm{div} \\
& =10 \text { volt }
\end{aligned}
$$

Untuk tegangan yang terbaca pada multimeter digital yaitu 9V, selisih nilai ini terjadi karena tingkat ketelitian antara osiloskop dan multimeter digital yang berbeda.

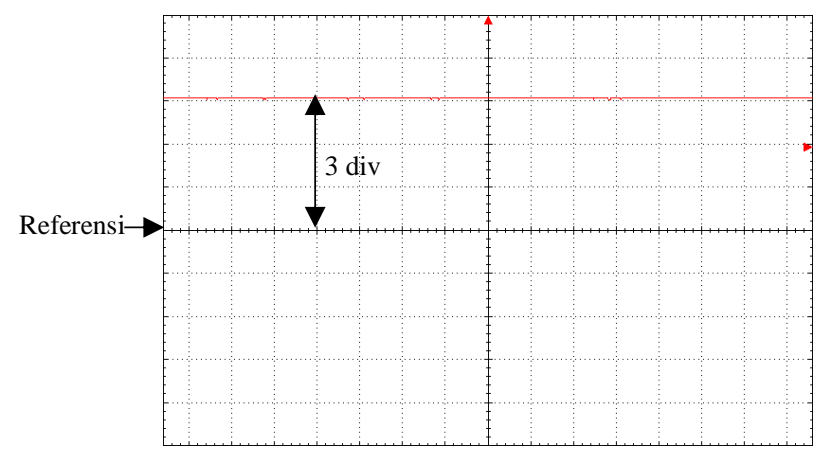

Gambar 8. Gelombang Tegangan Keluaran Sisi 15V dengan Beban Resistif 330 $\Omega$. V/div $=5 \mathrm{~V}, \mathrm{~T} / \mathrm{div}=$ $20 \mu \mathrm{s}$

Sedangkan untuk Gambar 8. merupakan gelombang tegangan keluaran sisi $15 \mathrm{~V}$ dari konverter arus searah tipe

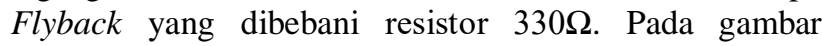

tersebut terlihat besarnya tegangan yaitu sebesar 3 div sehingga dapat dihitung besaran tegangan keluaran sebagai berikut.

$V_{D C}=3 \operatorname{div} \times 5 \mathrm{~V} / \mathrm{div}$

$$
=15 \text { volt }
$$

Untuk tegangan yang terbaca pada multimeter digital yaitu $14,83 \mathrm{~V}$, selisih nilai ini terjadi karena tingkat ketelitian antara osiloskop dan multimeter digital yang berbeda.

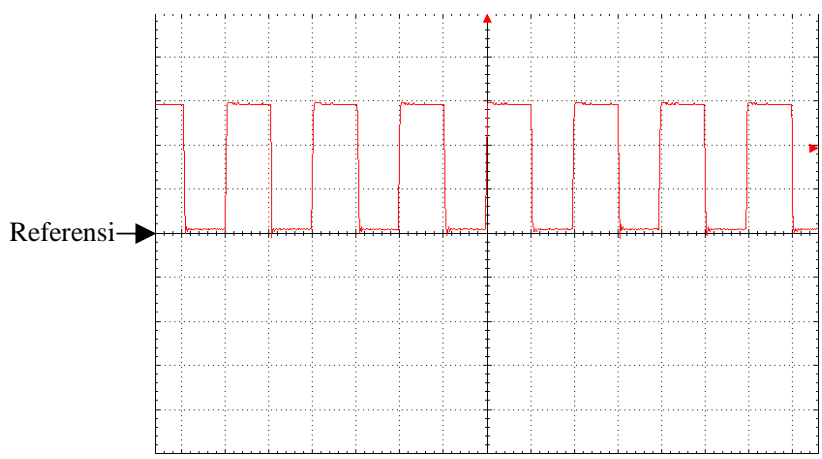

Gambar 9. Gelombang Sinyal PWM ketika Dibebani Resistor 47 $\Omega$. V $/ \mathrm{div}=5 \mathrm{~V}, \mathrm{~T} / \mathrm{div}=20 \mu \mathrm{s}$

Gambar 9. menunjukkan gelombang sinyal PWM ketika konverter arus searah tipe Flyback dengan umpan balik tegangan dibebani resistor $47 \Omega$. Osiloskop menunjukkan PWM yang dihasilkan memiliki duty cycle 52,5\%. Besar keluaran duty cycle PWM tersebut merupakan hasil respon IC TL494 terhadap tegangan keluaran konverter ketika dibebani resistor $47 \Omega$.

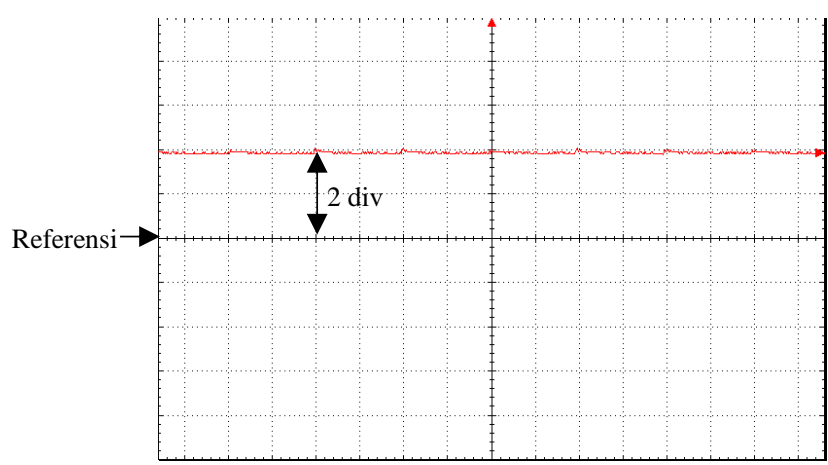

Gambar 10. Gelombang Tegangan Keluaran Sisi 9V dengan Beban Resistif $47 \Omega$. V/div $=5 \mathrm{~V}, \mathrm{~T} / \mathrm{div}=20 \mu \mathrm{s}$

Gambar 10. merupakan gelombang tegangan keluaran sisi $9 \mathrm{~V}$ dari konverter arus searah tipe Flyback dengan umpan balik tegangan dibebani resistor 330 2 . Pada Gambar 10., terlihat besarnya tegangan yaitu sebesar 2 div sehingga dapat dihitung besaran tegangan keluaran sebagai berikut.

$V_{D C}=2 \operatorname{div} \times 5 \mathrm{~V} / \mathrm{div}$

$=10$ volt 
Untuk tegangan yang terbaca pada multimeter digital yaitu 9V, selisih nilai ini terjadi karena tingkat ketelitian antara osiloskop dan multimeter digital yang berbeda.

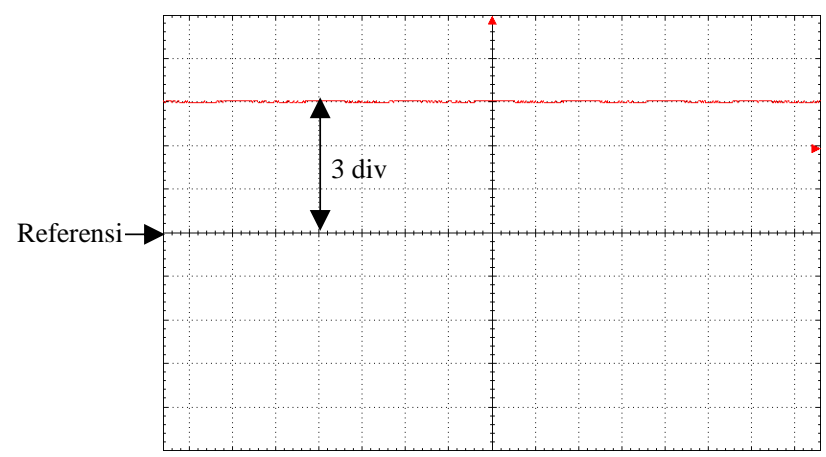

Gambar 11. Gelombang Tegangan Keluaran Sisi 15V dengan Beban Resistif 47 $\Omega$. V/div $=5 \mathrm{~V}, \mathrm{~T} / \mathrm{div}=$ $20 \mu \mathrm{s}$

Sedangkan untuk Gambar 11. merupakan gelombang tegangan keluaran sisi $15 \mathrm{~V}$ dari konverter arus searah tipe Flyback yang dibebani resistor $47 \Omega$. Pada gambar tersebut terlihat besarnya tegangan yaitu sebesar 3 div sehingga dapat dihitung besaran tegangan keluaran sebagai berikut.

$$
\begin{aligned}
V_{D C} & =3 \text { div } \times 5 \text { V/div } \\
& =15 \text { volt }
\end{aligned}
$$

Untuk tegangan yang terbaca pada multimeter digital yaitu $14,57 \mathrm{~V}$, selisih nilai ini terjadi karena tingkat ketelitian antara osiloskop dan multimeter digital yang berbeda. Dengan memvariasikan beban resistif dari $330 \Omega$ sampai $47 \Omega$ maka dapat dibuat Tabel 1. sebagai berikut.

Tabel 1. Pengujian Konverter Arus Searah Tipe Flyback dengan Umpan Balik Tegangan

\begin{tabular}{cccccccc}
\hline $\begin{array}{c}\text { Beban } \\
(\Omega)\end{array}$ & Vin (V) & $\begin{array}{c}\text { lin } \\
\text { (A) }\end{array}$ & $\begin{array}{c}\text { Vout } \\
\text { 9V (V) }\end{array}$ & $\begin{array}{c}\text { lout } \\
\text { 9V } \\
\text { (A) }\end{array}$ & $\begin{array}{c}\text { Vout } \\
\mathbf{1 5 V} \\
\text { (V) }\end{array}$ & $\begin{array}{c}\text { lout } \\
\mathbf{1 5 V} \\
(\mathbf{A})\end{array}$ & $\begin{array}{c}\text { Duty } \\
\text { Cycle } \\
(\%)\end{array}$ \\
\hline 330 & 12,04 & 0,13 & 9,0 & 0,08 & 14,83 & 0,04 & 24,2 \\
270 & 12,04 & 0,17 & 9,0 & 0,09 & 14,83 & 0,05 & 27,3 \\
220 & 12,05 & 0,19 & 9,0 & 0,09 & 14,83 & 0,07 & 31,0 \\
180 & 12,05 & 0,21 & 9,0 & 0,11 & 14,83 & 0,08 & 34,0 \\
120 & 12,05 & 0,31 & 9,0 & 0,13 & 14,82 & 0,12 & 41,0 \\
100 & 12,05 & 0,35 & 9,0 & 0,15 & 14,80 & 0,13 & 45,5 \\
82 & 12,05 & 0,44 & 9,0 & 0,17 & 14,77 & 0,17 & 50,5 \\
68 & 12,04 & 0,55 & 9,0 & 0,19 & 14,73 & 0,21 & 51,0 \\
56 & 12,04 & 0,68 & 9,0 & 0,21 & 14,62 & 0,28 & 52,0 \\
47 & 12,04 & 0,77 & 9,0 & 0,24 & 14,57 & 0,30 & 52,5 \\
& & & & & & &
\end{tabular}

Tabel 1. menunjukkan nilai tegangan masukan, arus masukan, tegangan keluaran, arus keluaran, dan duty cycle dari pengujian konverter arus searah tipe Flyback dengan umpan balik tegangan. Sedangkan Gambar 12. menunjukkan grafik tegangan keluaran konverter arus searah tipe Flyback dengan umpan balik tegangan terhadap beban resistif dan Gambar 13. menunjukkan grafik arus keluaran konverter arus searah tipe Flyback dengan umpan balik tegangan terhadap beban resistif.

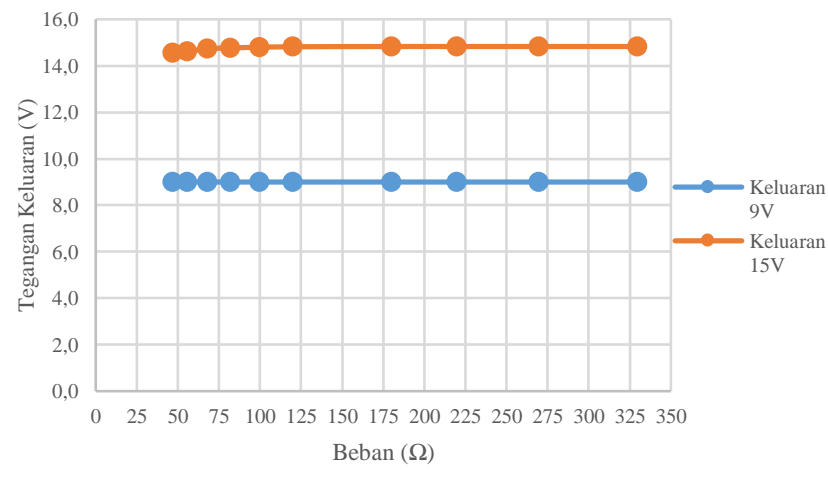

Gambar 12. Grafik Tegangan Keluaran Konverter Arus Searah Tipe Flyback dengan Umpan Balik Tegangan

Tabel 1. dan Gambar 12. menunjukkan tegangan keluaran dari konverter arus searah tipe Flyback dengan umpan balik tegangan. Terlihat masih adanya perubahan nilai tegangan pada sisi keluaran $15 \mathrm{~V}$ ketika penambahan nilai beban resistif. Penurunan tegangan ini disebabkan karena pada sisi keluaran $15 \mathrm{~V}$ tidak mempengaruhi besar tegangan masukan pin 1 IC TL494 seperti yang dilakukan oleh sisi keluaran 9V. Hal tersebut menyebabkan pada sisi keluaran $15 \mathrm{~V}$ hanya menyesuaikan perubahan duty cycle dari sisi keluaran 9V.

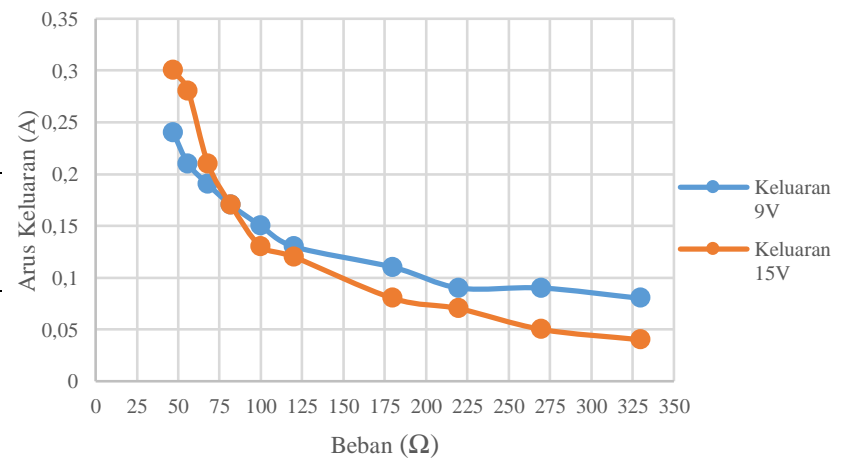

Gambar 13. Hubungan Variasi Beban Resistif dengan Arus Keluaran Konverter Arus Searah Tipe Flyback Menggunakan Umpan Balik Tegangan

Tabel 1. juga ditunjukkan pengaruh variasi beban resistif terhadap arus keluaran konverter arus searah tipe Flyback. Dapat dilihat pada Gambar 13. hubungan antara beban resistif dengan arus keluaran konverter arus searah tipe Flyback menggunakan umpan balik tegangan yaitu semakin besar nilai resistansi suatu beban maka arus keluaran semakin kecil, begitu juga sebaliknya apabila 
nilai resistansi suatu beban semakin kecil maka arus keluaran yang dihasilkan semakin besar.

Pada Tabel 1. terlihat bahwa duty cycle ketika diberi beban $330 \Omega$ bernilai $24,2 \%$ dan mengalami perubahan pada beban $270 \Omega$ menjadi $27,3 \%$ dikarenakan konverter arus searah tipe Flyback menggunakan mode umpan balik tegangan. Pada saat beban berubah maka tegangan keluaran juga akan berubah dan mempengaruhi nilai tegangan masukan pin 1 IC TL494 sehingga keluaran error amplifier IC TL494 akan dibandingkan dengan gelombang gergaji pada komparator untuk mengeluarkan gelombang duty cycle yang lebih kecil atau lebih besar untuk mendapatkan tegangan keluaran konverter seperti yang ditetapkan.

Berdasarkan Tabel 1. dan Gambar 12. ketika konverter diberi beban resistif bernilai $330 \Omega$ tegangan keluarannya sebesar 9V untuk sisi keluaran 9V dan 14,83V untuk sisi keluaran $15 \mathrm{~V}$. Kemudian saat beban berubah menjadi $47 \Omega$ tegangan keluaran konverter di sisi keluaran $9 \mathrm{~V}$ tetap stabil pada tegangan $9 \mathrm{~V}$ namun pada sisi keluaran $15 \mathrm{~V}$ menjadi $14,57 \mathrm{~V}$, terdapat penurunan tegangan pada sisi keluaran $15 \mathrm{~V}$ sebesar $0,26 \mathrm{~V}$ karena pada sisi keluaran $15 \mathrm{~V}$ tidak mempengaruhi besar tegangan masukan pin 1 IC TL494 seperti yang dilakukan oleh sisi keluaran 9V. Hal tersebut menyebabkan pada sisi keluaran $15 \mathrm{~V}$ hanya menyesuaikan perubahan duty cycle dari sisi keluaran $9 \mathrm{~V}$.

Penjelasan di atas menunjukkan hubungan antara beban resistif dengan tegangan keluaran konverter arus searah tipe Flyback dengan umpan balik yaitu semakin besar maupun kecil resistansi suatu beban maka tegangan keluaran akan relatif stabil pada tegangan yang diatur sebesar 9V dan 15V. Pada Gambar 13. terlihat hubungan antara nilai beban resistif dengan arus keluaran konverter arus searah tipe Flyback dengan umpan balik tegangan yaitu semakin besar nilai resistansi suatu beban maka arus keluaran semakin kecil, begitu juga sebaliknya apabila nilai resistansi suatu beban semakin kecil maka arus keluaran yang dihasilkan semakin besar.

\subsection{Pengujian Efisiensi Konverter Arus Searah tipe Flyback}

Efisiensi konverter arus searah tipe Flyback dengan umpan balik dapat dicari dengan menghitung daya input $\left(P_{\text {in }}\right)$ dan daya output $\left(P_{\text {out }}\right)$ pada konverter arus searah tipe Flyback dengan umpan balik dengan variasi beban antara $330 \Omega-$ $47 \Omega$, dengan menggunakan persamaan berikut.

$\eta=\frac{P_{O U T}}{P_{I N}} \times 100 \%$ dimana

$P_{I N}=V_{I N} \times I_{I N}$

$P_{\text {OUT }}=V_{\text {OUT }} \times I_{\text {OUT }}$

$P_{I N}=$ Daya masukan $(\mathrm{W})$

$P_{\text {OUT }}=$ Daya keluaran $(\mathrm{W})$

Persamaan 4 digunakan untuk mengetahui seberapa besar efisiensi dari konverter arus searah tipe Flyback dengan umpan balik tegangan pada penelitian ini dalam persentase. Untuk efisiensi konverter arus searah tipe Flyback yang dirancang dengan dua tegangan keluaran ini adalah $75 \%$. Nilai ini mengacu pada estimasi efisiensi konverter arus searah tipe Flyback untuk aplikasi tegangan keluaran rendah yaitu sebesar 70\% - 75\% [11]

Hasil perhitungan besar efisiensi konverter arus searah tipe Flyback dengan umpan balik tegangan dapat dilihat pada Tabel 2. berikut.

Tabel 2. Perhitungan Efisiensi Konverter Arus Searah tipe Flyback dengan Umpan Balik Tegangan

\begin{tabular}{|c|c|c|c|c|c|c|c|c|c|c|c|}
\hline $\begin{array}{c}\mathbf{R} \\
(\Omega)\end{array}$ & $\begin{array}{l}\text { Vin } \\
\text { (V) }\end{array}$ & $\begin{array}{l}\text { lin } \\
\text { (A) }\end{array}$ & $\begin{array}{c}\text { Vout } \\
9 \mathrm{~V} \\
\text { (V) }\end{array}$ & $\begin{array}{l}\text { lout } \\
9 \mathrm{~V} \\
\text { (A) }\end{array}$ & $\begin{array}{l}\text { Vout } \\
15 \mathrm{~V} \\
\text { (V) }\end{array}$ & $\begin{array}{l}\text { lout } \\
15 \mathrm{~V} \\
\text { (A) }\end{array}$ & $\begin{array}{l}\text { Pin } \\
\text { (W) }\end{array}$ & $\begin{array}{l}\text { Pout } \\
9 \mathrm{~V} \\
\text { (W) }\end{array}$ & $\begin{array}{l}\text { Pout } \\
15 \mathrm{~V} \\
\text { (W) }\end{array}$ & $\begin{array}{c}\text { Pout } \\
\text { Total } \\
\text { (W) }\end{array}$ & $\begin{array}{c}\eta \\
(\%)\end{array}$ \\
\hline 330 & 12,04 & 0,13 & 9,0 & 0,08 & 14,83 & 0,04 & 1,57 & 0,72 & 0,59 & 1,31 & 83,90 \\
\hline 270 & 12,04 & 0,17 & 9,0 & 0,09 & 14,83 & 0,05 & 2,05 & 0,81 & 0,74 & 1,55 & 75,80 \\
\hline 220 & 12,05 & 0,19 & 9,0 & 0,09 & 14,83 & 0,07 & 2,29 & 0,81 & 1,04 & 1,85 & 80,72 \\
\hline 180 & 12,05 & 0,21 & 9,0 & 0,11 & 14,83 & 0,08 & 2,53 & 0,99 & 1,19 & 2,18 & 86,01 \\
\hline 120 & 12,05 & 0,31 & 9,0 & 0,13 & 14,82 & 0,12 & 3,74 & 1,17 & 1,78 & 2,95 & 78,93 \\
\hline 100 & 12,05 & 0,35 & 9,0 & 0,15 & 14,80 & 0,13 & 4,22 & 1,35 & 1,92 & 3,27 & 77,63 \\
\hline 82 & 12,05 & 0,44 & 9,0 & 0,17 & 14,77 & 0,17 & 5,30 & 1,53 & 2,51 & 4,04 & 76,21 \\
\hline 68 & 12,04 & 0,55 & 9,0 & 0,19 & 14,73 & 0,21 & 6,62 & 1,71 & 3,09 & 4,80 & 72,54 \\
\hline 56 & 12,04 & 0,68 & 9,0 & 0,21 & 14,62 & 0,28 & 8,19 & 1,89 & 4,09 & 5,98 & 73,08 \\
\hline 47 & 12,04 & 0,77 & 9,0 & 0,24 & 14,57 & 0,30 & 9,27 & 2,16 & 4,37 & 6,53 & 70,45 \\
\hline
\end{tabular}

Pada Tabel 2. terlihat nilai efisiensi dari konverter arus searah tipe Flyback dengan umpan balik tegangan memiliki efisiensi tertinggi sebesar $86,01 \%$ pada beban $180 \Omega$ dan efisiensi terendah pada beban $47 \Omega$ dengan efisiensi sebesar 70,45\%. Rata-rata efisiensi dari konverter arus searah tipe Flyback dengan umpan balik tegangan sebesar $77,53 \%$.

Pada Gambar 14. menunjukkan grafik hubungan antara efisiensi konverter arus searah tipe Flyback terhadap beban resistif. Efisiensi konverter arus searah tipe Flyback dengan umpan balik tegangan memiliki rata-rata efisiensi sebesar $77,53 \%$. 


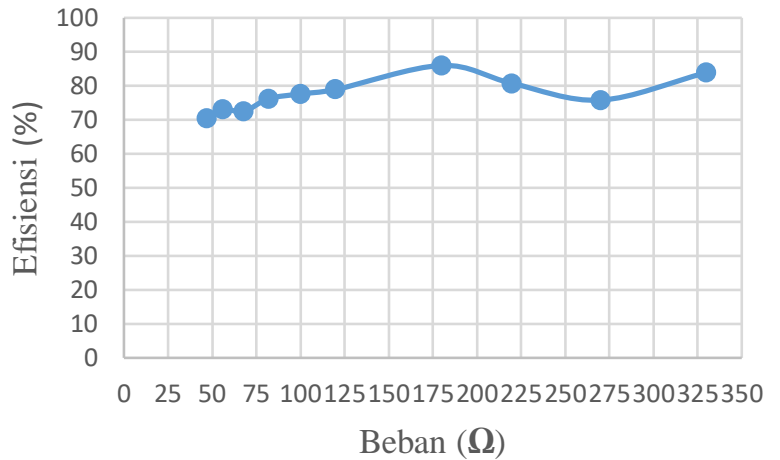

Gambar 14. Grafik Hubungan Efisiensi Konverter Arus Searah tipe Flyback dengan Umpan Balik Tegangan Terhadap Variasi Beban Resistif

Dapat dilihat pada Gambar 14. untuk efisiensi tertinggi ketika konverter dibebani resistor $180 \Omega$ yaitu $86,01 \%$. Sedangkan efisiensi terendah dialami konverter saat diberi resistor sebesar $47 \Omega$ yaitu $70,45 \%$, hal ini dikarenakan adanya disipasi daya pada dioda output di masing-masing sisi tegangan keluaran. Pada sisi tegangan keluaran 9V ketika dibebani resistor $47 \Omega$ arus yang mengalir sebesar $0,24 \mathrm{~A}$ dan voltage drop dioda SR5100 adalah $0,85 \mathrm{~V}$ sehingga terjadi disipasi daya 0,204W. Kemudian di sisi tegangan keluaran $15 \mathrm{~V}$ ketika dibebani resistor $47 \Omega$ arus yang mengalir sebesar $0,30 \mathrm{~A}$ dan voltage drop dioda SR5100 adalah $0,85 \mathrm{~V}$ sehingga terjadi disipasi daya $0,255 \mathrm{~W}$. Sehingga total disipasi daya kedua dioda output ini ketika dibebani resistor $47 \Omega$ adalah $0,459 \mathrm{~W}$.

Dari pengujian ini, diperoleh hasil bahwa efisiensi konverter arus searah tipe Flyback telah memenuhi kriteria pada rancangan awal.

\section{Kesimpulan}

Pada pengujian konverter arus searah tipe Flyback dengan umpan balik tegangan di sisi keluaran 9V diperoleh tegangan keluaran tetap terjaga sebesar $9 \mathrm{~V}$ ketika diberi variasi beban resistif $330 \Omega$ sampai $47 \Omega$. Namun di sisi keluaran $15 \mathrm{~V}$ terdapat penurunan tegangan dari $14,83 \mathrm{~V}$ dengan beban $330 \Omega$ ke $14,57 \mathrm{~V}$ dengan beban $47 \Omega$ karena pada sisi keluaran $15 \mathrm{~V}$ hanya menyesuaikan perubahan duty cycle dari sisi keluaran 9V. Dari pengujian juga diperoleh efisiensi tertinggi sebesar $86,01 \%$ pada beban $180 \Omega$ dan efisiensi terendah pada beban $47 \Omega$ sebesar $70,45 \%$. Rata-rata efisiensi dari konverter arus searah tipe Flyback dengan umpan balik tegangan adalah sebesar $77,53 \%$. Hasil tersebut telah memenuhi kriteria efisiensi pada perancangan awal. Penelitian ini dapat dikembangkan kedepannya dengan menambahkan umpan balik arus dan mengaplikasikan pengiriman sinyal umpan balik terisolasi.

\section{Referensi}

[1]. D. W. Hart, Power Electronics. McGraw-Hill, 2011.

[2]. Y. Sawitra, "PERANCANGAN 7,3 W MULTIPLE OUTPUT SELF OSCILLATING FLYBACK CONVERTER," 2017.

[3]. A. S. Putra, T. Andromeda, and A. Warsito, "REALISASI KONVERTER DC-DC TIPE PUSHPULL BERBASIS IC TL494 DENGAN UMPAN BALIK TEGANGAN," TRANSIENT, vol. 6, pp. 1-8, 2017.

[4]. E. S. D. Prakoso, T. Andromeda, and B. Winardi, "PERANCANGAN KONVERTER ARUS SEARAH ZETA VOLTAGE FEEDBACK MENGGUNAKAN IC TL494," no. November, 2017.

[5]. L. W. Cahyadi, T. Andromeda, and M. Facta, "KINERJA KONVERTER ARUS SEARAH TIPE BUCK CONVERTER DENGAN UMPAN BALIK TEGANGAN BERBASIS TL494,” vol. 6, 2017.

[6]. "IRF540N HEXFET ${ }^{\circledR}$ Power MOSFET," International Rectifier, pp. 1-9.

[7]. "Schottky Barrier Rectifier," no. 1, RECTRON SEMICONDUCTOR, 2006, pp. 9-10.

[8]. Rubycon, "RADIAL LEAD ALUMINUM ELECTROLYTIC CAPACITORS," 2016.

[9]. "TL494 Pulse-Width-Modulation Control Circuits," TEXAS INSTRUMENT, 2017.

[10]. Analog Devices, "Decoupling Techniques," in Application Note, Analog Devices, 2009, pp. 1-14.

[11]. H.-S. Choi, "Application Note AN4137 Design Guidelines for Off-line Flyback Converters Using Fairchild Power Switch (FPS)," FAIRCHILD SEMICONDUCTOR, 2003, pp. 1-22. 